\title{
Performance analysis of solar assisted ground coupled heat pump system in Latvia
}

\author{
Lana Migla ${ }^{1}$, Andrejs Snegirjovs ${ }^{2}$, Olga Shutenkova ${ }^{1}$ \\ ${ }^{1}$ Riga Technical university, str.Kipsala 6, Riga, Latvia \\ ${ }^{2}$ Institute of Physical energetics, str.Krivu, Riga, Latvia
}

\begin{abstract}
Today, with the increased popularity and availability of renewable energy sources the question of ensuring a proper household heating, that is energy, is not as complicated as it used to be. Users are embracing the environmental sustainability stand and are turning to heat pumps and solar panels as means of providing heat for their homes. The geothermal heat pump and solar thermal panels energy efficiency rates coupled make these the perfect choice for those, who are concerned about the impact they make on the environment-aspiring to zero emission buildings. The combined system of solar thermal panels and ground source heat pump for heating capacity $13 \mathrm{~kW}$ will be developed. The main novelty is the investigation of a new type of a solar thermal accumulation tank. Hypothetically this solar assisted ground coupled heat pump system should reach COP rate 4 and reduce electricity demand consumption by $40 \%$. To find out the truth of proposed thesis, the research will be carried out. Both simulation and real-life object data analysis will be performed. As a result, the potential of such a system in northern latitudes will be determined.
\end{abstract}

\section{Introduction}

As regarded the reduction of $\mathrm{CO}_{2}$ in the energy sector and the introduction of the concept of passive buildings in the building sector, different alternative heating solutions should be explored and their usefulness increased. Country-specific climate in the northern latitudes provides a large proportion of energy consumption for heating and hot water needs, mainly in the period from October to April. In addition, the ground heat pump's maximum efficiency yield accounts for the October-December period, and the lowest efficiency rate is recorded for the time frame between February and April [1]. Unfortunately, the solar radiation duration and intensity depend on the season, weather conditions and geographical position of a country. As compared with the annual global solar radiation incident on horizontal surfaces in sunny regions $\left(2200 \mathrm{kWhm}^{-2}\right)$, in the northern Europe it is half as much $\left(1100 \mathrm{kWhm}^{-2}\right)$ [2]. While for solar thermal system, the highest efficiency rate (during the cold season) is limited to the January-March period, and the lowest between November and December. Therefore, these two distinct heating systems complement each other in a quite productive manner. Nowadays, eco-friendly and at the same time cost efficient is not as puzzling as it used to be a few decades ago. In order to make the most out of energy sources that to a certain extent are available in an endless supply, a combination of solar energy generating appliances and ground source heat obtaining pumps is favoured. In literature, there are numerous studies about utilization of solar energy in solar assisted systems and mainly with heat pumps. $[3,4]$ in their study, a solar assisted heat pump (SAHP) heating system powered by flat plate collector is compared energetically and financially with a conventional heat pump system for various climates. The main characteristics of the solar assisted ground coupled heat pump are established. The simulation is performed with TRNSYS, and study shows that the COP of SAHP heating systems was found over 4 for cold climates; a very important result which indicates the use of this technology in difficult weather conditions. Research must be done to investigate the SAHP potential in northern latitudes. The main advantage of a combined system, compared to the conventional heat pumps, is the higher coefficient of performance (COP) due to the higher heat source temperature level. So as a novelty of this paper is the study of innovative thermo solar tank filled with bioethanol.

The research and calculation part presents the analysis of the automated collected system data. Heat and electricity system's efficiency has been performed and its ecological assessment has been carried out.

\section{Methods}

The research will be carried out in two different waysboth data analysing from the object and performing simulations in the modelling program. The investigation will be done in the object located near Salaspils $56^{\circ} 51^{\prime} 38,1^{\prime \prime} \mathrm{N} 24^{\circ} 19^{\prime} 12,8^{\prime \prime} \mathrm{E}$. It is a mansion with heated area $195 \mathrm{~m}^{2}$. The system has been in operation since 2017. Characteristics of the private house: 2 floors,

\footnotetext{
* Corresponding author: Lana.Migla@rtu.lv
} 
heating area: 1st floor $103.1 \mathrm{~m}^{2}$, 2nd floor $86.7 \mathrm{~m}^{2}$. House walls from indoor to outdoor consist of doubled plasterboard $24 \mathrm{~mm}$, air gap $70 \mathrm{~mm}$, aerated concrete block $300 \mathrm{~mm}$, rockwool $100 \mathrm{~mm}$ and decoration. The floor is insulated with Styrofoam $100 \mathrm{~mm}$ and the roof is insulated with rockwool $150 \mathrm{~mm}$. Only natural ventilation exists in the house. This is a temperate cold climatic zone with annual average temperature $+6{ }^{\circ} \mathrm{C}$, area is not windy, but humidity is high, and average global solar radiation on horizontal plate is almost 1100 $\mathrm{kWh} / \mathrm{y} .8$ pcs TS400 Thermosolar - flat vacuum type solar collectors are installed on the roof orientation $12^{\circ}$ East South, and collector tilt angle $45^{\circ}$. Heat pump is power variable, nominated $\mathrm{SEER}=2.96$ and electrical power consumption up to $13 \mathrm{~kW}$. Low temperature floor heating is used. Total heating area is almost $200 \mathrm{~m}^{2}$. The energy audit report estimates that the heat energy consumption of building construction is $50 \mathrm{kWh} / \mathrm{m}^{2}$. DHW set temperature is $55{ }^{\circ} \mathrm{C}$. DHW consumption profile is like the residential consumption profile -2 adults, both working, 2 children and one senior not working. Declared load profiles for DHW could be marked with L [9]. Exist DHW circulation, loop is only $17 \mathrm{~m}$, Dn16. DHW consumption is fully covered, DHW temperature reduction at the consumption side not detected. According to principal schematic, system has 2 accumulation tanks. First tank is $1 \mathrm{~m}^{3}$ with $100 \mathrm{~mm}$ insulation, main task is heat buffer. Well temperature stratification is a specific requirement for this element bottom part is for DHW preheating by using direct solar collectors' energy; middle part is for room heating, and top part is for DHW after heating by using solar collector and heat pump combined operation. Second accumulation tank is for inlet temperature of heat pump rising by using solar energy. This technical solution raises COP of the system, because momental COP of the heat pump is strongly dependent on the temperature difference between inlet temperature on energy source side and outlet temperature on consumption side. Electricity consumption: $23 \mathrm{kWhm}^{-2}$ per year for heating and domestic hot water preparation. The underfloor low temperature (till $35^{\circ} \mathrm{C}$ ) heating system is the main consumer of the heat. The Cottage has a close type heating system, where the heat carrier is technical water (demineralized and deaired).

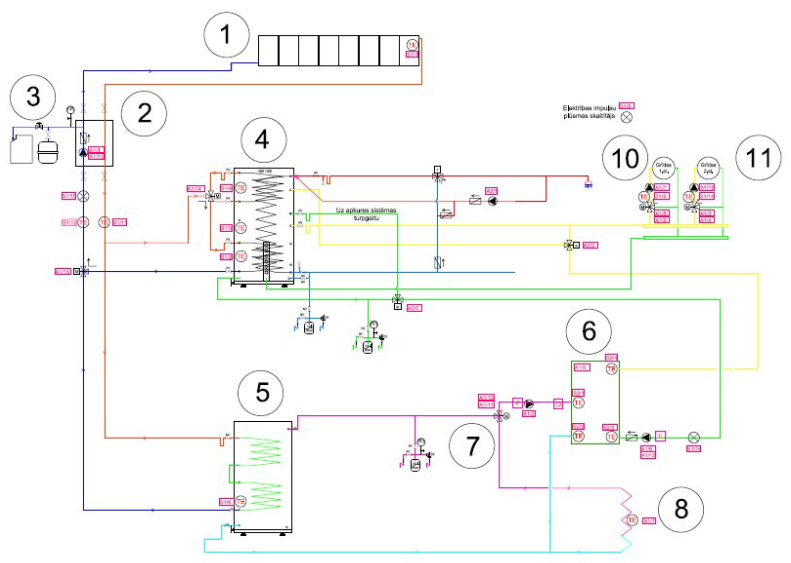

Fig. 1. Heating system scheme

1. Vacuum flat plate solar collectors filled with krypton gas,

2. Solar collector loop circulation pump,

3. Expansion tank suitable for solar thermal energy,

4. DHW and heating combined tank 1000L for heating support,

5. Bioethanol storage tank 3001 ,

6. Heat pump $\mathrm{Q}_{\mathrm{h}}-13 \mathrm{~kW}$,

7. Mixer for horizontal earth collector,

8. Horizontal heat pump ground collector $1500 \mathrm{~m}$,

9. DHW loop circulation pump,

10. $1^{\text {st }}$ floor heating loop circulation pump,

11. $2^{\text {nd }}$ floor heating loop circulation pump.

The combined heating system has 2 parts- ground heat pump with nominal load $13 \mathrm{~kW}$, ground heat pump pipe system is built in $2 \mathrm{~m}$ depth, and solar heating system that consists of 8 flat plate vacuum collectors. Solar collectors are connected due to copper pipes with solder connections. As a non-freezing heat carrier in system flows propylene glycol. The heat load of solar collector block is $11,5 \mathrm{~kW}$, collectors are filled with krypton gas [5], therefor it is possible to use solar energy more effectively than usual during heating season. The convection minimisation is achieved by replacing the remaining air with a more suitable gas - such as krypton. As it is known, the biggest drawbacks of an evacuated collector design are the costs for the hydraulics and where applicable - valves and the complex casing design compared to conventional approaches. Flat plate collectors are known to need no maintenance and incur little or no cost during the lifetime, unlike some evacuated flat plate collectors. These collectors must be periodically re-evacuated and re-filled with krypton.

In Latvia global solar irradiance is $1100 \mathrm{kWhm}^{-2}$, in cloudy period $350 \mathrm{kWhm}^{-2}$, but in winter $200 \mathrm{kWhm}^{-2}$ on average [2]. Heat energy produced in one-hour period by solar collector system is calculated by equation.

$$
Q_{\text {solar }}=S \times \eta \times Q,
$$

Where $S$ - area of solar collectors, $\mathrm{m}^{2}$; $\eta$ - efficiency of solar collectors; $Q-$ solar irradiance, $\mathrm{kWhm}^{-2}$.

They provide water heating in a sanitary combined tank with three heat exchangers, 1st. heat exchanger solar circuit heats the bottom of the tank, 2nd heat exchanger - solar circuit heats the top of the tank, 3rd heat exchanger - heats hot water through the whole tank. The solar power output is primarily transferred to the tank's first heat exchanger, placed in the top of the tank for a rapid heating of hot water to provide the consumer with a continuous supply of hot water. If there is enough solar irradiation, solar collectors heat the barrel up and pass it from the top of the heat exchanger barrel to the flow at the bottom of the barrel, the kind of solar contour heats the whole barrel, both top and bottom. When the solar power is not enough, the solar contours of the heat 
carrier are below the top temperature of the storage tank, and solar collectors are able to heat only the bottom of the tank. In order to protect the solar collector from overheating during the summer period, the system shall be equipped with a regulating valve and a heat exchanger which ensures the discharge of excess solar heat to the ground collector through the reverse of the heat pump. In the coldest period of the year, solar energy is stored in a storage tank filled with bioethanol 3001. The storage tank makes it possible for a multi-stage compression device to be used for the solar heating system. It must be mentioned that the capacity of the accumulation tank is 10001 . The amount of heat energy to warm up 10001 water till $55^{\circ} \mathrm{C}$ is calculated as follows:

$$
Q_{h r}^{h}=1,16 q_{h r}^{h}\left(55-t^{C}\right)+Q^{h t}
$$

Where $q_{h r}^{\text {h }}$ - hourly calculation consumption of hot water, $\mathrm{m} 3 / \mathrm{h}$;

$t^{c}$ - hot water temperature, ${ }^{\circ} \mathrm{C}$;

$Q^{h t}$ - Heat flow losses at the calculation stage, $\mathrm{kW}$.

Consequently, the time period (h) that is needed to warm up the accumulation tank till $55^{\circ} \mathrm{C}$ is calculated as follows:

$$
t=\frac{Q_{h r}^{h}}{Q_{\text {solar }}},
$$

The amount of heat produced by the heat pump and the solar collector system is calculated by the heat output formula 4:

$$
Q=c m\left(t_{2}-t_{1}\right) T
$$

where

$m$ - thermal flow rate $[1 / \mathrm{h}]$;

$C$ - the specific calorific value of the substance $[\mathrm{kJ} / \mathrm{kgK}]$;

$t_{1}$ - the starting temperature of the substance $\left[{ }^{\circ} \mathrm{C}\right]$;

$t_{2}$ - end temperature of the substance $\left[{ }^{\circ} \mathrm{C}\right]$;

$T$ - time step equal to $0.03611[\mathrm{~h}]$.

The performance of heat pumps can be characterised by the transformation factor $\xi$, i.e. the ratio of the amount of heat to the work consumed, calculated by the formula:

$$
\xi=q / l=q /\left(q-q_{l}\right)
$$

where $q$-amount of heat generated in the heat pump, kJ $l$ - Storage energy, $\mathrm{kJ}$

$q_{l}$ - amount of heat received from the heat source, $\mathrm{kJ}$

The transformation factor depends on the technological (pump and compressor) parameters and temperature levels of auxiliary equipment. The less the temperature increases, the higher the transformation factor will become. This means that the heat pumps work most effectively in low-temperature heating systems (up to $\left.+55^{\circ} \mathrm{C}\right)$.
It is therefore important that the temperature difference between the heat source and the heating system is as small as possible. The dynamics of the change in the transformation factor of the heat pump, depending on the temperature difference between the external heat source and hot water, are illustrated in Figure 2.

The higher the efficiency of the heat pump, the quicker it pays off.

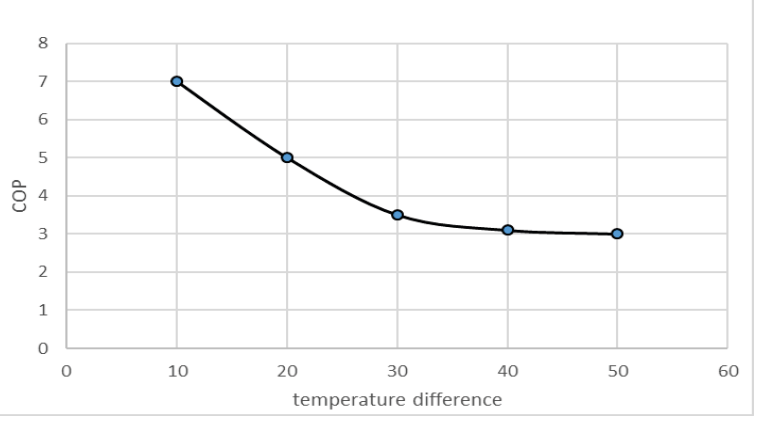

Fig. 2. COP dependence of temperature difference

\section{Results}

As a result, the max heat energy load in one-hour period from solar collector system was calculated and determined that at high solar irradiance $Q_{\text {solar } \max }=14,58$ $\mathrm{kWh}$, but at low solar irradiance $Q_{\text {solar } \min }=5,10 \mathrm{kWh}$. And therefore, the amount of heat energy to warm up accumulation tank till $55^{\circ} \mathrm{C}$ was calculated $Q_{h r}^{h}=52,20 \mathrm{kWh}$.

But the Time period (h) for this process is at high solar irradiance $t=3 \mathrm{~h} 35 \mathrm{~min}$.

The novelty is an innovative thermo solar tank with a volume $300 \mathrm{~L}$ with three heat exchangers. First solar loop heats up the lowest layer of the accumulation tank. Second solar loop heats up the top layer of the tank, but the third -DHW tank in tank. As a heat carrier the bioethanol is used, its temperature in ground loop $+4^{\circ} \mathrm{C}$. Solar collector system increases this temperature up to $25^{\circ} \mathrm{C}$. As it is known, the higher the temperature in the storage tank is, the less heat energy the pump needs to use for work, and at the same time, less electricity for heat production. [6-7].

In Solar tank the solar energy is transferred to first heat exchanger, that's located in the bottom for quick DHW heating to provide the consumer with continuous supply of hot water. If solar radiation is sufficient then solar collectors warm up the top layer of solar tank and at the same time return the flow (supply) from heat exchangers top layer has been transferred as an inflow in lower layer, as a result the solar loop warms up in the top as well as in the bottom. In case of the solar radiation insufficiency, the temperature of the heat carrier is lower than the temperature on top of the accumulation tank and the solar collector system is only capable of heating up the bottom of the solar tank.

Using modelling software based on the measurements, the relationship between outside 
temperature, hot water demand, and solar energy yield was established.

In order to describe the operation of the heat pump, based on measurements, the energy load profile was modelled.

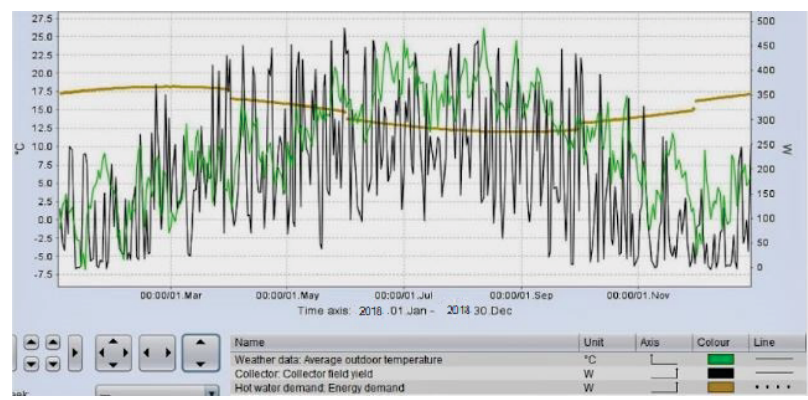

Fig. 3. DHW, outside temperature, solar energy yield profile

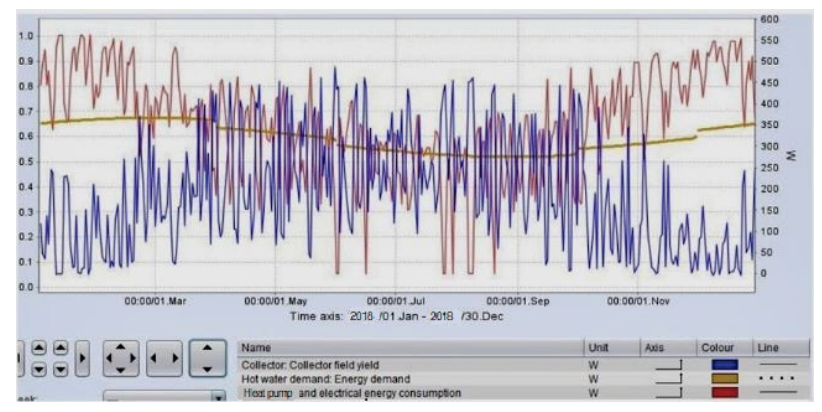

Fig. 4. DHW, heat pump energy consumption, solar energy yield profile

The Benefits of a Solar Panel and Heat Pump Combination will provide a full-scale heating in the winter. In the summer, the ground source heat pump would discard the excess of heat produced by the solar collectors and store a part of it for the winter. Based on previous load profiles, the produced heat graph by sources was developed.

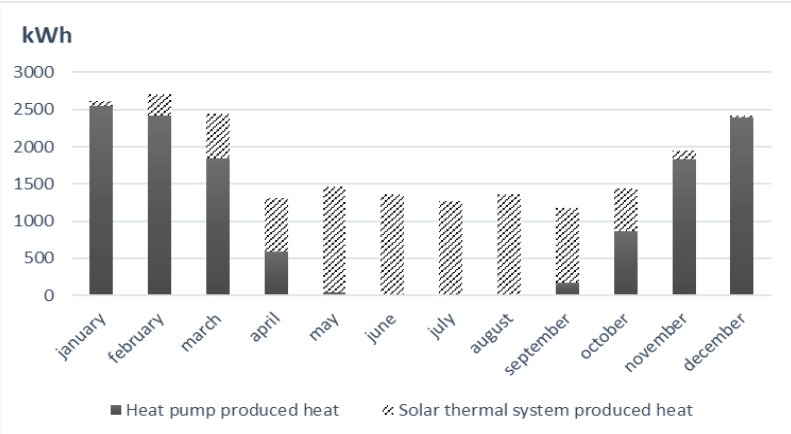

Fig.5. Produced heat by source

It was calculated that in total the heat pump produced $12709 \mathrm{kWh}$ of heat capacity, while the solar collector $8780 \mathrm{kWh}$ in 2018, of which $4129 \mathrm{kWh}$ was discharged into the storage tank for further increases in the thermal input temperature of the ground circuit (an analytical algorithm was developed to determine this size, setting the conditions as the system's automatically do not have a specific sensor).
The comparison of the data obtained with the data described in the literature shows the relevance of the data obtained with previous studies. The amount of heat consumption of the installation shall be $66 \mathrm{kWh} / \mathrm{m} 2$, which shall be the undertaking, taking into account the temperature comfort level requirements of the particular consumer. According to literature [8], increasing room temperature by $1{ }^{\circ} \mathrm{C}$ increases energy consumption by 5 $6 \%$ per year. It was calculated that the energy consumed for heating and hot water preparation is $4385 \mathrm{kWh}_{2}$ for heating circulation pumps $144 \mathrm{kWh}$. So transformation factor $\xi$ is 3.98. The transformation factor of the heat pump is higher than expected, indicating a high efficiency of the solar heat pump system. Hypothesis has confirmed that the efficiency of the solar heat pump system is close to $1: 4$.

The solar heat pump system has a long lifetime, easy maintenance and depends solely on electricity. These factors justify initial large investments. According to studies carried out in Europe, electricity savings through the solar heating system range from $30 \%$ to $40 \%$, which indicates a high sustainability of the system $[3,8]$. Using the direct coupled calculator, the annual electricity consumption for the heating of a given site is estimated to be $10167 \mathrm{kWh}$ for the installation of the heat pump system without the support of the solar system. Comparing the data obtained, the electricity consumed at the installation $4241 \mathrm{kWh}$ shows a $40 \%$ electricity consumption savings. Assuming that $\mathrm{CO}_{2}$ emission factor for heating is $0.264, \mathrm{t}_{\mathrm{CO} 2} / \mathrm{MWh}$, but for electricity generation and transmission $0.397, \mathrm{t} / \mathrm{MWh}$. Reduction of $\mathrm{CO}_{2}$ emissions achieved by producing heat energy by SAHP -2,08 [ $\mathrm{t}_{\mathrm{CO} 2} /$ year], which is a significant reduction of carbon footprints. These results justify the usefulness of such systems to achieve the objectives of the European Union in the field of energy efficiency and renewable resources. As annual cost efficiency was calculated - 7830,1591 [Eur/t $\mathrm{CO}_{\mathrm{CO}}$ year], the repayment of such systems makes them attractive to users by encouraging the construction of passive buildings.

\section{Conclusions}

Solar assisted ground coupled heat pump system is a good alternative source of heating, with a view to reducing the greenhouse effect and increasing the greening of the fighting environment. Transformation factor of solar assisted ground coupled heat pump system in Latvia is 3.98. Comparing the data obtained from the electricity demand shows a $40 \%$ of electricity savings, it can also be expressed as 2,08 [ $\mathrm{tCO} 2 /$ year] carbon footprint reduction. In the system, solar collectors produced approximately $40 \%$ of the energy demand.

\section{References}

1. R. Bogdanovičs, A.Borodinecs, A. Zajacs, K. Šteinerte. Review of heat pumps application potential in cold climate. Advances in Intelligent Systems and Computing, 692, 543. (2018); 
2. P.Shipkovs, A.Snegirjovs, J.Shipkovs, G.Kashkarova, K.Lebedeva, L.Migla, Solar Thermal Cooling on the Northernmost Latitudes. Energy Procedia. 70, 510. (2015);

3. E.Bellos, C.Tzivanidis (2017). Energetic and financial sustainability of solar assisted heat pump heating systems in Europe. Sustainable Cities and Society.14, 70.(2017);

4. M.S. Buker, S.B. Riffat. Solar assisted heat pump systems for low temperature water heating applications: A systematic review Renewable and Sustainable Energy Reviews, 55, 399. (2016);

5. F.Buttinger, T.Beikircher, M.Pröll, W. Schölkopf. Development of a new flat stationary evacuated CPC-collector for process heat applications. Solar Energy. 84, Issue 7, 1166. (2010);

6. S.J.Sterling,M.R.Collins. Feasibility analysis of an indirect heat pump assisted solar domestic hot water system. Apply Energy 93:11-7. (2012);

7. A.Borodinecs, R.Bogdanovics, A. Prozuments, J.Tihana, B.Gaujena. Evaluation of hybrid heating systems with a combination of fossil and renewable energy sources. Earth and Environmental Science, 297. (2019) ;

8. V.A. Kostenko, N.M.Gafiyatullina, A.A. Semchuk, I.M.Kukolev. Geothermal heat pump in the passive house concept. Magazine of Civil Engineering, 68(8), 18. (2016).

9. Commission Delegated Regulation (EU) No 812/2013 of 18 February 2013 supplementing Directive 2010/30/EU of the European Parliament and of the Council with regard to the energy labelling of water heaters, hot water storage tanks and packages of water heater and solar device 